\title{
Effect of season on Ejaculate Quality of three phenotypes of Nigerian Local Cocks
}

\author{
Machebe, N.S and Ezekwe, A.G \\ Department of Animal Science, University of Nigeria, Nsukka, Nigeria.
}

\begin{abstract}
Twenty four (24) adult Nigerian local cocks comprising 8 normal, 8 frizzle and 8 naked-neck were subjected to wo ejaculations per week for seven weeks in each season (early rain. late rain, early dry and late dry seasons) using the massage technique. Ejaculates were subjected to both physical and chemical evaluations. Results showed a significant $(P<0.01)$ seasonal effects between ohenotypes in reaction time. In all the seasons, naked-neck and.frizzle cocks had higher $(P<0.01)$ ejaculate volume, sperm motility and total sperm than normal cocks. A highly significant $(P<0.01)$ phenotype by season interaction was observed with naked-neck producing better quality ejaculates during the dry season when compared to other phenotypes. Significant $(P<0.05)$ differences were noted in the percent abnormal sperm among the seasons. There were no significant season by phenotype interactions $(P>0.05)$ in most of the chemical parameters $\left(\mathrm{Na}, \mathrm{K}, \mathrm{Ca}^{2}, \mathrm{Mg}^{2}\right.$, and total protein) evaluated. However, a gradual increase ir seminal protein was observed among the phenotypes with a peak during late dry season. The caions (particularly sodium, potassium and calcium) and chloride constituents of ejaculates were significantly lower during the late dry season than at most other seasons. From these results it was concluded that the naked-neck and frizzle cocks appear superior to the normal cocks in semen output and quality under the humid tropical environment.
\end{abstract}

Keywords: Season, Ejaculate, Phenotypes, local cocks

\section{Introduction}

One of the ways to enhance the commercial values of the local chickens is to improve their fertility and breeding performance. This may be achieved through the utilization of advantageous gene complexes in breeding strategies. Horst 1988 , identified nine major genes of the indigenous chicken that can be used in genetic improvement programmes. Among these include the riahad-neck ( $\mathrm{Na}$ ) and frizzle (F) genes which anded ir our wal chicken populations. Birds, which possess hese genes. need to be exploited for the development of viable indigenous poultry industry.

Unfortunately, these phenotypes have been grossly neglected probably as a result of their physical appearances, which make them unattractive. Available evidence (Merat 1986) has shown that these birds maintain their productive potential even at high ambient temperatures $\left(30^{\circ} \mathrm{C}\right.$ and above) when compared with the normal feathered birds. Adverse reactions to high ambient temperatures have been regarded as the major factor inhibiting poultry production in hot 
climates (Horst 1989). In Nigeria, most of the published works on the major genes are limited to their effect on growth and laying performances. Thus, there is a paucity of information on the semen production/quality of naked neck and frizzle cocks under the humid tropical environment. This study was therefore undertaken to evaluate the effect of season on semen quality of three phenotypes of Nigeria local cocks under the humid tropical environment.

\section{Materials and Methods}

Three groups of mature local cocks made up of 8 frizzle, 8 normal and 8 naked neck were purchased from the local markets in Enugu state. Their body weights ranged from $1.38 \pm 0.0 \mathrm{lkg}$ to $1.48 \pm 0.0 \mathrm{l}$ $\mathrm{kg}$. The previous management background of the cocks was unknown. Phenotypically, the plumage of the naked-neck and frizzle bird differentiates them from the normal cocks. In the naked-neck cock, the zones separating the pterylae or apteria are entirely devoid of feathers. In addition, certain pterylae are substantially reduced, not only in the neck area bu: also on the breast, thigh and other parts (Merat, 1986). Frizzle birds, on the other hand are characterized by imperfect feathers, and with primary feathers curling outward and forward (Obioha, 1992). The cocks were quarantined for two weeks.

Management of cocks: At the end of the quarantine period, each group of cocks was housed separately in a deep litter and was fed commercial growers poultry ration containing $15 \%$ crude protein ad libitum. Cool drinking water was provided ad libitum also.

Semen collection and evaluation: After quarantine, 2 wecks pre-experimental period were used to train the cocks for semen collection by the massage technique described by Burrows and Quinn (1937). This was considered necessary not only for effective semen collection but also to make the cocks familiar with the semen collector. Actual semen collection and evaluation lasted for four scasons classified as early rainy season (April to June), late rainy season (July to September), early dry season (October to December) and late dry season (January to March). The average temperature and relative humidity during the experimental period are shown in Table 1.

Two ejaculates were collected from each cock weekly between $0800 \mathrm{hr}$ and $1000 \mathrm{hr}$ for seven wceks in each season. Reaction time of each cock was recorded with a stop watch. Ejaculates were subjected to both physical and chemical evaluations. Physical evaluations involved the determination of semen colour, semen volume, sperm concentration, progressive sperm motility and percentage abnormal sperm as described by Zemjanis (1970). After the physical evaluation, the remaining portions of semen of cocks in each

TABLE 1. Average daily minimum and maximum temperature and relative humidity during the experimental period.

\begin{tabular}{lcccc}
\hline Season & \multicolumn{2}{c}{ Daily Temperature $\left({ }^{\circ} \mathrm{C}\right)$} & \multicolumn{2}{c}{ Relative Humidity (\%) } \\
& min & $\max$ & Gam & 6pm \\
\hline Early rain & 22.40 & 30.58 & 79.11 & 70.29 \\
Late rain & 20.61 & 29.08 & 78.75 & 83.13 \\
Early dry & 22.32 & 31.41 & 78.09 & 66.87 \\
Late & 22.56 & 31.04 & 77.80 & 57.01 \\
\hline
\end{tabular}

Siverce: Meteorological Station. UNN Linkage Farm 
group were pooled and centrifuged at $3000 \mathrm{~g}$ for 10 minutes to obtain the seminal plasma. These were stored frozen at $-15^{\circ} \mathrm{C}$ until required for chemical analysis. The total protein in the semen was determined using SP400 UVIVIS spectrophotometer at $750 \mathrm{~nm}$ (Lowry et al 1951) whereas colorimetric procedure of Lindner and Mann (1960) was used to determine fructose concentration in the sample. Chloride ion in the sample was determined by Voldhard method (Pearson, 1976), while cations in the sample were evaluated by the method of Quinn et al., (1966) using the atomic absorption spectrophotometer. Data were arranged in a $3 \times 4$ factorial arrangement and analyzed using SPSS (2001).

\section{Results and Discussion}

A total of 1000 samples were analyzed out of 1344 ejaculates collected, 344 ejaculates being considered unfit for analysis. Results on the physical and cherrical characteristics of semen of the three phenotypes are summarized in Tables 2 and 3. Results showed a significant $(P<0.01)$ seasonal effects between breeds in reaction time. Naked neck cocks were ejaculated at a relatively shorter time than the frizzle and normal cocks during all the seasons. However, during the late rainy season, all the cocks were ejaculating at relatively the same time interval, implying that the cocks reacted faster during the cooler periods of the year. A longer reaction time was generally observed in the cocks at late dry season. This implies that generally, the high environmental temperatures prevalent during this period affected the ability of cocks to ejaculate even though the threc phenotypes reacted differently. $\Lambda$ highly significant $(P<0.01)$ seasonal influence was observed in ejaculate volume, sperm concentration, sperm motility and total sperm among the phenotypes. Phenotypes by season interaction was also significant $(P<0.01)$. The ejaculate volume of normal cocks during early rain and early dry seasons were higher than ejaculates obtained during late rainy season. Ejaculate volumes of naked-neck and frizzle cocks were not significantly affected during the early rainy seasons. The cocks produced larger ejaculates in late dry season than the other seasons. Results also showed a general reduction in ejaculate quality of cocks of all phenotypes in the late rainy season. This observation is in accord with those of Bonadonna and Pozzi (1959), Saied and AI-Soudi (1975) and Egbunike and Nkanga (1999). The observed variations in ejaculates quality among seasons may be a reflection of seasonal changes in spermatogenesis and semen production which according to Onuora (1982) would be expected as a result of some changes in day length during different seasons. It has been observed by Saied and AI-Soudi (1975), Egbunike and Nkanga (1999), that the dry season period has a positive effect on sperm production of cocks as a result of increased photoperiod, which normally occurs during dry season in the tropics. This may account for the increase in ejaculate quality observed in the dry season. According to Parker et ol (1942), Saied and AI-Soudi (1975) after exposure of cocks to light for prolonged period, sperm production eventually declines probably as a result of testicular rest or reduced feed intake or hoth.

Although there were no significantly season $x$ phenotype interaction, naked-neck and frizzle cocks had significantly more $(\mathrm{P}<0.05)$ abnormal sperm cells in the late dry and late rain/late dry seasons, respectively. In contrast, normal cocks had its highest abnormal sperm cells during early rainy season. However, within breeds differences in abnormal sperm cells were highly pronounced. Furthermore, in all the phenotypes, there were significantly $(P<0.01)$ more sperm cells in the ejaculates during late dry season. It is therefore likely that the high proportion of abnormal sperm cells in ejaculates obtained in the late dry season 
Table 2: Effect of season on physical characteristics of cock semen

\begin{tabular}{|c|c|c|c|c|c|}
\hline \multirow[b]{2}{*}{ Parameters } & \multirow[b]{2}{*}{ Season } & \multicolumn{3}{|c|}{ Phenotypex } & \multirow[b]{2}{*}{ Overalt. } \\
\hline & & Naked-Neck & Frizde & Normul & \\
\hline $\begin{array}{l}\text { Reaction time } \\
\text { (seconds) }\end{array}$ & $\begin{array}{l}\text { E.R } \\
\text { L.R } \\
\text { E.D } \\
\text { L.D } \\
\text { Overall }\end{array}$ & $\begin{array}{l}12.11=0.41^{\mathrm{a}} \\
13.09 \pm 0.58 \\
12.39 \pm 0.42^{\mathrm{a}} \\
13.29 \pm 0.47^{\mathrm{a}} \\
12.72 \pm 0.47^{\mathrm{s}}\end{array}$ & $\begin{array}{l}14.46 \pm 0.55^{\mathrm{b}} \\
14.20 \pm 0.58 \\
13.75 \pm 0.52^{\text {ib }} \\
14.32 \pm 0.52^{\mathrm{a}} \\
14.18 \pm 0.54^{\mathrm{Ns}}\end{array}$ & $\begin{array}{l}14.23 \pm 0.59^{b} \\
12.39 \pm 0.54 \\
14.46 \pm 0.57^{b} \\
15.73 \pm 0.48^{b} \\
15.46 \pm 0.55^{\mathrm{NS}}\end{array}$ & $\begin{array}{c}13.60 \pm 0.52^{k *} \\
14.89 \pm 0.57^{\mathrm{NS}} \\
13.54 \pm 0.50^{\circ *} \\
14.45 \pm 0.49^{\circ} \\
14.12 \pm 0.52^{\mathrm{NS}}\end{array}$ \\
\hline $\begin{array}{l}\text { Ejaculate } \\
\text { Volume (ml) }\end{array}$ & $\begin{array}{l}\text { E.R } \\
\text { L.R } \\
\text { E.D } \\
\text { L.D } \\
\text { Overall }\end{array}$ & $\begin{array}{l}0.27 \pm 0.01^{\mathrm{w}} \\
0.24 \pm 0.01^{\mathrm{a}} \\
0.30 \pm 0.01^{\mathrm{b}} \\
0.42 \pm 0.01^{\mathrm{c}} \\
\mathbf{0 . 3 1} \pm 0.01^{*}\end{array}$ & $\begin{array}{l}0.24 \pm 0.01^{\mathrm{a}} \\
0.24 \pm 0.01^{\mathrm{a}} \\
0.30 \pm 0.01^{\mathrm{b}} \\
0.38 \pm 0.02^{\mathrm{k}} \\
0.29 \pm 0.01^{*}\end{array}$ & $\begin{array}{l}0.24 \pm 0.01^{w 0} \\
0.20 \pm 0.200^{\mathbf{w}} \\
0.24 \pm 0.01^{i b} \\
0.35 \pm 0.01^{x} \\
0.26 \pm 0.01^{*}\end{array}$ & $\begin{array}{l}0.25 \pm 0.01^{*} \\
0.23 \pm 0.01^{* *} \\
0.28 \pm 0.01^{\star *} \\
0.39 \pm 0.01^{* *} \\
0.29 \pm 0.01^{* *}\end{array}$ \\
\hline $\begin{array}{l}\text { Sperm } \\
\text { concentration } \\
\qquad\left(\times 10^{9} / \mathrm{mL}\right)\end{array}$ & $\begin{array}{l}\text { E.R } \\
\text { L.R } \\
\text { F.D } \\
\text { I.D } \\
\text { Orerall }\end{array}$ & $\begin{array}{l}2.35 \pm 0.08^{b} \\
2.05 \pm 0.04^{\mathrm{bo}} \\
3.01 \pm 0.100^{\mathrm{c}} \\
2.76 \pm 1) .06^{\mathrm{bd}} \\
2.54 \pm 0.07^{*}\end{array}$ & $\begin{array}{l}2.21 \pm 0.04^{*} \\
2.12: \pm 0.04^{: \mathrm{b}} \\
2.77 \pm 0.07^{\circ} \\
3.03 \pm 0.09^{*} \\
2.53 \pm 0.06^{* *}\end{array}$ & $\begin{array}{l}2.17 \pm 0.04^{\mathrm{b}} \\
1.76 \pm 0.05^{a} \\
2.53 \pm 0.07^{\mathrm{a}} \\
2.47 \pm 0.06^{\mathrm{ac}} \\
2.23 \pm 0.06^{\mathrm{a}}\end{array}$ & $\begin{array}{l}2.24 \pm 0.05^{\kappa *} \\
1.98 \pm 0.04^{* *} \\
2.77 \pm 0.06^{* *} \\
2.57 \pm 0.05^{* \star} \\
2.43 \pm 0.06^{* \pi}\end{array}$ \\
\hline $\begin{array}{c}\text { Sperm notility } \\
(\%)\end{array}$ & $\begin{array}{l}\text { E.R } \\
\text { L.R } \\
\text { E.D } \\
\text { I.D } \\
\text { Overall }\end{array}$ & $\begin{array}{l}67.59 \pm 0.85^{\mathrm{ib}} \\
69.46 \pm 0.89^{\mathrm{ab}} \\
69.20 \pm 0.97^{\mathrm{b}} \\
72.77 \pm 0.72^{\mathrm{bc}} \\
70.11=0.86^{* 4}\end{array}$ & $\begin{array}{l}71.88 \pm 1.08^{2 h x} \\
69.02 \pm 0.81^{a} \\
69.20 \pm 0.97^{11} \\
72.50 \pm 0.69^{3} \\
70.65 \pm 0.89^{* x}\end{array}$ & $\begin{array}{l}67.59 \pm 0.85^{\mathrm{a}} \\
67.77 \pm 0.94 \\
67.41 \pm 1.00 \\
68.93 \pm 1.19^{\mathrm{a}} \\
\mathbf{6 7 . 9 2} \pm 0.50^{\mathrm{NS}}\end{array}$ & $\begin{array}{l}69.02 \pm 0.93^{n *} \\
68.75 \pm 0.88^{\mathrm{NS}} \\
69.08 \pm 0.98^{\mathrm{NS}} \\
71.40 \pm 0.87^{n n} \\
69.56 \pm 0.92^{\mathrm{NS}}\end{array}$ \\
\hline $\begin{array}{l}\text { Total sperm } \\
\left(\times 10^{\circ}\right)\end{array}$ & $\begin{array}{l}\text { E.R } \\
\text { L.R } \\
\text { E.D } \\
\text { L.D } \\
\text { Overalt }\end{array}$ & 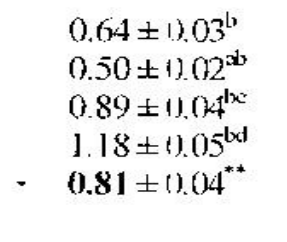 & $\begin{array}{l}0.55 \pm 0.03^{3 b} \\
0.51 \pm 0.02^{a b} \\
0.83 \pm 0.03^{b} \\
1.18 \pm 0.05^{b c} \\
0.77 \pm 0.03^{x *}\end{array}$ & $\begin{array}{c}0.52 \pm 0.03^{\mathrm{a}} \\
0.38 \pm 0.01^{\mathrm{a}} \\
0.60 \pm 0.03^{\mathrm{a}} \\
0.88 \pm 0.04^{\mathrm{w}} \\
0.59 \pm 0.03^{* *}\end{array}$ & $\begin{array}{l}0.57 \pm 0.03^{*} \\
0.46 \pm 0.02^{* \star} \\
0.77 \pm 0.03^{* \star} \\
1.08 \pm 0.05^{n *} \\
0.72+0.03^{* *}\end{array}$ \\
\hline $\begin{array}{l}\text { Total } \\
\text { sperm }\left(10^{9}\right)^{\text {mrotile }}\end{array}$ & $\begin{array}{l}\text { E.R } \\
\text { L.R } \\
\text { E.D } \\
\text { L.D } \\
\text { Overall }\end{array}$ & $\begin{array}{l}0.18 \pm 0.01^{\mathrm{ab}} \\
0.16 \pm 0.01^{\mathrm{ib}} \\
0.21 \pm 0.01^{\mathrm{b}} \\
0.30 \pm 0.01^{\mathrm{c}} \\
0.22 \pm 0.01^{\text {** }}\end{array}$ & $\begin{array}{l}0.17 \pm 0.01^{\mathrm{th}} \\
0.17 \pm 0.01^{\mathrm{bb}} \\
0.21 \pm 0.01^{\mathrm{is}} \\
0.28 \pm 0.01^{\mathrm{bc}} \\
0.21 \pm 0.01^{* *}\end{array}$ & $\begin{array}{l}0.16 \pm 0.01^{\mathrm{d}} \\
0.14 \pm 0.03^{\mathrm{a}} \\
0.16 \pm 0.01^{\mathrm{ah}} \\
0.24 \pm 0.01^{\mathrm{kc}} \\
0.17 \pm 0.02^{* *}\end{array}$ & $\begin{array}{l}0.17 \pm 0.01^{\star} \\
0.16 \pm 0.01^{\kappa *} \\
0.19 \pm 0.01^{n \star} \\
0.28 \pm 0.01^{\star *} \\
0.20 \pm 0.01^{* \star}\end{array}$ \\
\hline $\begin{array}{l}\text { Abnornul sperm } \\
(\%)\end{array}$ & $\begin{array}{l}\text { E.R } \\
\text { L.R } \\
\text { E.D } \\
\text { L.D } \\
\text { Overall }\end{array}$ & $\begin{array}{l}8.00 \pm 0.34^{\mathrm{a}} \\
8.77 \pm 0.42^{\mathrm{a}} \\
8.34 \pm 0.41^{\mathrm{a}} \\
9.98 \pm 0.46^{\mathrm{h}} \\
8.77 \pm 0.41^{\circ}\end{array}$ & $\begin{array}{l}7.88 \pm 0.32^{7} \\
8.52 \pm 0.48^{36} \\
8.10 \pm 0.42^{3} \\
9.46 \pm 0.52^{\mathrm{d}} \\
8.49 \pm 0.44^{\circ}\end{array}$ & $\begin{array}{l}9.59 \pm 0.47^{k} \\
7.64 \pm 0.38^{b} \\
7.70 \pm 0.30 \\
8.20 \pm 0.39^{1} \\
8.28 \pm 0.41^{1 *}\end{array}$ & $\begin{array}{l}8.49 \pm 0.38^{* *} \\
8.31 \pm 01.43^{N S} \\
8.04 \pm 0.11^{\mathrm{NS}} \\
9.21 \pm 0.46^{* *} \\
8.51 \pm 0.42^{* *}\end{array}$ \\
\hline
\end{tabular}

E.R - Early; L.R-Late rain, E.D-Early; L.D Late dry:

a.l.c.d. row and columm means with different superseripts are statistically different at $1 \%$ or $5 \%$ * - $\mathrm{P}<0.05, \quad * *-\mathrm{P}<0.01$, NS -- Not significant 
Table 3: Effect of season on chemical characteristics of cock semen

\begin{tabular}{|c|c|c|c|c|c|}
\hline \multirow[b]{2}{*}{$\begin{array}{l}\text { Parameters } \\
\text { (ng/100mI) }\end{array}$} & \multirow[b]{2}{*}{ Season } & \multicolumn{3}{|c|}{ Phenotypes } & \multirow[b]{2}{*}{ Overall } \\
\hline & & Naked-Neck & Frizhe & Nomnxl & \\
\hline Total protein & $\begin{array}{l}\text { ER } \\
\text { LR } \\
\text { ED } \\
\text { LD } \\
\text { Overall }\end{array}$ & $\begin{array}{l}23.74 \pm 1.46^{a} \\
24.14 \pm 2.23^{a} \\
47.90 \pm 1.79^{b} \\
49.07 \pm 1.27^{k} \\
36.21 \pm 1.69^{* *}\end{array}$ & $\begin{array}{l}24.32 \pm 1.54^{\mathrm{b}} \\
22.64 \pm 1.21^{\mathrm{a}} \\
45.11 \pm 1.98^{\mathrm{b}} \\
46.91 \pm 2.45^{\mathrm{b}} \\
\mathbf{3 4 . 7 5} \pm 1.80^{* *}\end{array}$ & $\begin{array}{l}22.48 \pm 1.10^{\mathrm{a}} \\
22.26 \pm 1.03^{\mathrm{a}} \\
45.66 \pm 154^{\mathrm{b}} \\
49.53 \pm 1.05^{\mathrm{b}} \\
\mathbf{3 4 . 9 8} \pm 1.18^{* *}\end{array}$ & $\begin{array}{l}23.51 \pm 1.37^{\mathrm{NS}} \\
23.02 \pm 1.49^{\mathrm{N}} \\
46.22 \pm 1.7^{\mathrm{s}} \\
48.50 \pm 1.59^{\mathrm{Ns}} \\
35.31 \pm 1.56^{\mathrm{NS}}\end{array}$ \\
\hline Chloride & $\begin{array}{l}\text { ER } \\
\text { LR } \\
\text { ED } \\
\text { LD } \\
\text { Overall }\end{array}$ & $\begin{array}{l}3.55 \pm 0.49^{1} \\
3.49 \pm 0.55^{12} \\
6.87 \pm 2.47^{\circ} \\
1.90 \pm 0.79^{4} \\
3.95 \pm 1.08^{*}\end{array}$ & $\begin{array}{l}3.89 \pm 0.327 \\
3.32 \pm 0.37 \\
3.9\left(1 \pm 2.12^{12}\right. \\
1.27 \pm 0.40^{3} \\
3.11 \pm 0.80^{*}\end{array}$ & $\begin{array}{l}3.90 \pm 0.28^{1} \\
3.73 \pm 0.31^{b} \\
4.89 \pm 2.28^{b} \\
1.56 \pm 0.30^{\prime} \\
\mathbf{3 . 5 2} \pm 0.79^{\prime}\end{array}$ & $\begin{array}{l}3.78 \pm 0.36^{N \mathrm{~N}} \\
3.51 \pm 0.41^{\mathrm{NS}} \\
5.24 \pm 229^{\mathrm{Ns}} \\
1.58 \pm 0.50^{\mathrm{NS}} \\
3.53+0.89^{\mathrm{NS}}\end{array}$ \\
\hline Sodium & $\begin{array}{l}\text { ER } \\
\text { LR } \\
\text { F.D } \\
\text { LD } \\
\text { Overal }\end{array}$ & $\begin{array}{l}17.39 \pm 0.09^{\mathrm{c}} \\
15.90 \pm 0.39^{\mathrm{b}} \\
4.36 \pm 0.13^{\mathrm{a}} \\
4.69 \pm 0.42^{\mathrm{a}} \\
10.58 \pm 0.26^{* *}\end{array}$ & $\begin{array}{l}17.34 \pm 0.07^{\mathrm{b}} \\
16.04 \pm 0.90^{\mathrm{b}} \\
4.21 \pm 0.15^{\mathrm{a}} \\
4.49 \pm 0.26^{\mathrm{a}} \\
10.52 \pm 1.35^{3 *}\end{array}$ & $\begin{array}{l}17.38 \pm 0.05^{\mathrm{c}} \\
14.87 \pm 0.66^{\mathrm{b}} \\
4.46 \pm 0.13^{\mathrm{a}} \\
4.19 \pm 0.14^{\mathrm{a}} \\
10.22 \pm 0.25^{* *}\end{array}$ & $\begin{array}{l}17.37 \pm 0.077^{\mathrm{W}} \\
15.60 \pm 0.68^{\mathrm{N}} \\
4.34 \pm 0.14^{\mathrm{Ns}} \\
4.45 \pm 0.27^{\mathrm{N}} \\
10.42 \pm 0.62^{\mathrm{N}}\end{array}$ \\
\hline Potassium & $\begin{array}{l}\text { ER } \\
\text { LR } \\
\text { ED } \\
\text { LD } \\
\text { Overall }\end{array}$ & $\begin{array}{l}16.82 \pm 1.21^{1 \mathrm{~b}} \\
13.74 \pm 1.27^{\mathrm{ab}} \\
13.17 \pm 0.80^{\mathrm{a}} \\
10.67 \pm 0.92^{\mathrm{a}} \\
13.60 \pm 1.05^{* *}\end{array}$ & $\begin{array}{l}15.67 \pm 1.77 \\
13.89 \pm 1.58 \\
13.26 \pm 0.84 \\
12.80 \pm 1.02 \\
13.91 \pm 1.30^{\mathrm{NS}}\end{array}$ & $\begin{array}{l}18.16 \pm 0.40^{\circ} \\
16.81 \pm 0.63^{\mathrm{k}} \\
14.87 \pm 0.84^{\mathrm{b}} \\
11.53 \pm 1.12^{4} \\
15.34 \pm 0.75^{* *}\end{array}$ & $\begin{array}{r}89 \pm 1.13^{w s} \\
4.81 \pm 1.16^{\mathrm{s}} \\
13.77 \pm 0.83^{\mathrm{w}} \\
11.66 \pm 1.02^{\mathrm{N}} \\
14.28 \pm 1.04^{\mathrm{w}}\end{array}$ \\
\hline Calcium & $\begin{array}{l}\text { ER } \\
\text { LR } \\
\text { ED } \\
\text { LD } \\
\text { Overall }\end{array}$ & $\begin{array}{l}2.98 \pm 0.58^{\mathrm{b}} \\
2.42 \pm 0.49^{\prime} \\
0.59 \pm 0.07^{1} \\
0.66 \pm 0.10^{\mathrm{a}} \\
\mathbf{1 . 9 2} \pm 0.31^{*}\end{array}$ & $\begin{array}{l}3.36 \pm 0.30^{\mathrm{b}} \\
2.94 \pm 0.19^{\mathrm{b}} \\
0.42 \pm 0.07^{\mathrm{a}} \\
0.63 \pm 0.133^{\mathrm{a}} \\
\mathbf{1 . 8 4} \pm 0.17^{*}\end{array}$ & $\begin{array}{l}3.70 \pm 0.49^{b} \\
3.24 \pm 0.27^{b} \\
0.46 \pm 0.07^{1} \\
0.60 \pm 0.17^{k} \\
\mathbf{2 0 0} \pm 0.25^{* *}\end{array}$ & $\begin{array}{l}3.35 \pm 0.46^{w} \\
2.87 \pm 0.32^{\mathrm{W}} \\
0.49 \pm 0.07^{\mathrm{w}} \\
0.60 \pm 0.17^{\mathrm{w}} \\
1.92 \pm 0.25^{\mathrm{N}}\end{array}$ \\
\hline Mkgnesium & $\begin{array}{l}\text { E.R } \\
\text { L.R } \\
\text { E.D } \\
\text { L.D } \\
\text { Overall }\end{array}$ & $\begin{array}{l}3.57 \pm 0.21^{\mathrm{a}} \\
3.07 \pm 0.14^{\mathrm{a}} \\
5.04 \pm 0.43^{\mathrm{b}} \\
4.78 \pm 0.25^{\mathrm{a}} \\
\mathbf{3 . 9 2} \pm 0.26^{* *}\end{array}$ & $\begin{array}{l}3.07 \pm 0.33^{31} \\
2.86 \pm 0.27^{1} \\
4.16 \pm 0.50^{6} \\
4.39 \pm 0.34^{b} \\
3.62 \pm 0.36\end{array}$ & $\begin{array}{l}3.79 \pm 0.19^{\mathrm{a}} \\
3.32 \pm 0.19^{\mathrm{a}} \\
4.33 \pm 0.16^{\mathrm{b}} \\
4.90 \pm 0.41^{\mathrm{b}} \\
4.09 \pm 0.24^{*}\end{array}$ & $\begin{array}{l}3.48 \pm 0.24^{N s} \\
3.09 \pm 0.20^{N s} \\
4.51 \pm 0.38^{N s} \\
4.43 \pm 0.38^{N s} \\
3.88 \pm 0.20^{N s}\end{array}$ \\
\hline
\end{tabular}

E.R - Eariy; L.R-Late rain, E.D-Early; L.D Late dry,

- r.t... row and column means with different superscripts are statistically different at $1 \%$ or $5 \%$

$*-\mathrm{P}<0.05$. ** $-\mathrm{P}<0.01$. NS - Not significant 
may be associated with high yield of sperm cells recorded during this period. Generally, nakedneck and frizzle cocks produced better ejaculates than their normal counterparts even in the dry season. This supports the view of Yunis and Cahaner (1994) that naked-neck and frizzle genes increase the critical upper limits of the body temperatures thereby promoting appetite even under heat stress.

The chemical characteristics of the semen of the three phenotypes (Table3) revealed that seminal protein rose significantly during late dry season above other seasons. According to Voglmayr and Ghandi (1978), protein in semen coats spermatozoa thereby stabilizing sperm cell membranes against adverse storage effect. It may be necessary to infer that the high seminal protein observed in late dry season might be a mechanism for cushioning the effect due to high environmental temperature experienced in that period. However, cations and chloride concentrations in the semen were generally and significantly lower during the late dry season than at most other seasons particularly sodium, potassium and calcium which have serious implications for cell membrane action and electrical activity at the cellular levels. This is in conformity with the report of Mann (1964) that breed and season influence most chemical characteristics of cock semen. The low total protein observed in this study during the rainy season suggests decreased epididymal duct contribution to the ejaculatc. It is likely that high environmental temperature and low relative humidity experienced in the dry season interferes with mechanisms involved in maintaining a balanced osmotic condition in ejaculated semen. This is because the influx of these ions into and efflux out of the spermatozoa are known to interfere with sperm viability (Quinn et al 1966).

\section{Conclusion}

This study has shown that semen quality of naked-neck and frizzle cocks was not adversely affected by the prevailing hot dry season temperatures as they did to that of normal cocks. Therefore, their inclusion in any breed improvement programme aimed at producing adaptable meat or egg type chickens suitable for use in the hot humid tropics would be beneficial.

\section{References}

Bonadonna, T and G.G, Pozzi, 1959 . Researches on spermatogenesis in Gallus under Different light and temperature conditions. Zootec, E Vet 14:194-208

Burrows, W.II and J.P Quinn,1937. The collection of spermatozoa from the domestic fowl and turkey. Poult. Sci .16:19-24

Egbunike, G.N and E.E Nkanga, 1999. Effect of breed and season on semen characteristics of the cock in the humid tropics . Trop. J Anim Sci 1:127-134

Ezekwe, A.G and N.S Machebe 2004. Effect of dry season on the ejaculate characteristics of three phenotypes of local cocks in the humid tropics Proc. $9^{\text {th }}$ Annual Confr.ASAN. Sept. $13^{\text {th }}$ $16^{\text {th } 2004 . ~ E b o n y i ~ S t a t e ~ U n i v ~ A b a k i l i k i ~}$ Nig. P239-24 ]

Horst, P.1988. Mature fowl as reservoir for genomes and major genes with direct and indirect effect on production adaptability. In:Proc. $18^{\text {th }}$ World Poultry Congr .Nagoya .Japan , 4-6 ${ }^{\text {th }}$ Sept 1988. P105. 
Merat, P .1986. Potential usefulness of $N a$ (naked neck) gene in poultry production . World Poultry Science Journal 42:124 - 142.

Lindner, H.R and T. Mann 1960. Relationship between the content of androgenic steroids in the testis and the secretary activity of seminal vesicle on the bull. J. Endocrinol. 21:341-360.

Lowry, O.H, Rosebrough N.I, Farr, A.C and R.G Randall, 1951 . Protein measurement with Folin phenol reagent. J Bio. Chem.193: 255273.

Obioha, F.C. 1992. A Guide to Poultry Production in the Tropics. Acena Publishers. Enugu

Onuora, C.I. 1982. Seasonal variation in semen quality in the guinea fowl. Nig Vet. J.I:8-15

Parker, J.E, Mckenzie, F.A and H.L. Kempfor, 1942. Fertility in the Male Domestic fowl. M.Agric . Expt. Station. Res No.347

Pearson ,D. 1976. The Chemical Analysis of Foods. $7^{\text {th }}$ ed. Churchill Livingstone, New York P402-452.

Quinn, P.J., White, I.G and B.R. Wrirrick, 1966. The effect of dilution on the concentration of $\mathrm{Na}^{+}, \mathrm{K}^{+}, \mathrm{Ca}^{2+}$ and $\mathrm{Mg}^{2+}$ in ram and bull semen. J. Reprod. Fertili, 12:131-139.

SPSS for windows .2001. Standard Version SPSS Ine. London.

Saied , J.M and AI-K .A. Soudi, 1975. Seasonal variation in semen characteristics of White Leghorn, New Hampshire and Indigenous chicken in Iraq. Brit. Poult. Sci. 16:91-102.

VogImayr, J.K. and J.S.Ghandi, 1978. Survival of ram testicular spermatozoa in vitro. Effect of glucose, glucose metabolites, rete testes fluid proteins, selected androgens and phospholipids. Theriogenol. 9:463-473.

Yunis, $\mathbf{E}$ and A. Cahaner. 1994. The effect of the frizzle (F) and Naked (Na) gene and their interaction on broiler at normal and high biet temperature . $5^{\text {th }}$ World congress 9 on Genetics Applied to livestock production, 20:25-30.

Zemjanis, R.1970. Collection and iduation of semen In Domestic and Therapeutic Technique in Animal Reproduction $2^{\text {nd }}$ ed. Williams and Wilkins Co. BaltimoreM.D.P139-156.

(Received I" Oct. 2005; Accepted 15 Jan. 2007) 